\title{
ネットワーク上の点分布から多層的集塊性を抽出する 空間分析手法の提案，及びその実装に関する研究
}

\section{塩出志乃・岡部篤行}

\section{A Network-Based Spatial Analytical Method for Detecting Agglomerations in a Point Distribution on a Network and Its Implementation}

Shino SHIODE and Atsuyuki OKABE

\begin{abstract}
Many kinds of phenomena, including traffic accidents, road kills of wild animals and distribution of urban facilities, occur on a network. To analyze their spatial patterns, this paper proposes a new spatial analytical method, called NT-VCM (Network Variable Clumping Method), as an extension of Variable Clumping Method on a plane, which we developed earlier and named PLN-VCM (Planar Variable Clumping Method). The major function of NT-VCM is to statistically detect significant multi-level network clumps in the distribution of points on a network using Monte Carlo simulations. Applying NT-VCM and PLN-VCM to the same data set, this paper shows that NT-VCM preserves connectivity of points on a network better than PLN-VCM.
\end{abstract}

Keywords: ネットワーク可変クランプ法 (network variable clumping method), 点分布分析 (point pattern analysis)、ネットワーク最小木 (network minimum spanning tree), 最短経路 (shortest path)

\section{1.はじめに}

害世界の現象には, 都市内のコンビニエンススト アの分布，犯罪の発生場所の分布など，点分布とし て記述できるような現象が多く存在する。それれを 対象とした分析の中で頻繁に用いられてきた手法に, 最近隣法 (Clark and Evans, 1954) やK 関数法 (Ripley, 1981）に代表されるような，点分布の均一ランダム 性，集塊性，拡散性を検出して，点分布の空間的偏 りを明らかにする方法がある．従来，これらの分析 法の多くは，2 次元平面上の点分布で表される現象 を対象としてきた.しかし，我々の身の回りを見て みると，例えば商店街や駅前繁華街の商業施設のよ

塩出：干113-8656 東京都文京区本郷 7-3-1

東京大学空問情報科学研究センター

Center for Spatial Information Science, University of Tokyo,

7-3-1 Hongo, Bunkyo-ku, Tokyo 113-8656, JAPAN

Tel 03-5841-6259

E-mail shino@ua.t.u-tokyo.ac.jp
うに，施設が道路ネットワークに沿って局所的に集 積している現象が見られる，また，交通事故や，車 と動物の衝突事故などは，道路上のある特定の場所 に集中して発生することがある．さらに，これらの 点分布をミクロなスケールで見てみると，隣接点ま での実測距離であるネットワーク距離と, 従来の分 析で用いられてきた直線距離が北離しているケース が少なくない．これらのことを考虑すると，ネット ワークに沿って分布している現象を分析対象とする 場合には，平面上で直線距離を使って分析するより， ネットワーク上で経路距離を使って分析する方が, より実態に即した結果が得られるのではないかと考 えられる。

ネットワーク上で詳細な分析を行うには，それに 耐えるデータが必要となる. 近年のデジタル空間デ 一夕の高精度化によって, 街区単位の細密な道路デ 
一タや，道路に接続した住宅，店舗等の各種建築物 を示す点的データの位置情報, 及びそれらに付随す る詳細な属性情報など，空間データの整備が急速に 進展してきた．それに伴い，これらのデータが擁す る豊富な情報量を生かし，より的確に都市空間の現 象を把握する分析手法への要望も高まってきている.

このような要望を背景に，90年代頃より徐々に， 道路ネットワーク上の点的施設を対象とした分析手 法が開発されてきている(例えば, Miller, 1994, 1999; Okabe and Okunuki, 2001; Okabe and Yamada, 2001; Okabe et al., 1995; 四茂野, 1993など). しかし, 平 面空間を対象とした分析手法に比べると未だ数が少 なく，体系的に確立されているとはいえない。

そこで本稿では，ネットワーク空間での空間分析 手法の一つとして, ネットワーク上における点分布 の中から, 多層的な集塊を抽出する統計的手法, 及 びその手法を実装する方法を提案する. 加えて, 同 一データに対して，ネットワークを想定した手法と 平面を想定した手法の両手法を適用し，ネットワー ク上での分析の有効性を検討することにする.

\section{2. ネットワーク可変クランプ法}

2. 1 クランプ, 及びネットワーク可変クランプ法

図 1 (a) に示した20点の点集合を使って, ネット ワーク上の多層的な集塊の簡単な例を示そう.これ らの点の中から, まず, 局所的な集塊を探すと, 図 1 (b)の点線で示されている, 非常に近接した 4 グ ループの点集合が確認できる。次に，図 1 (b)の集 塊と比べてより大局的な集塊を探すと, 図 1 (c)の 点線で示されているような, さらに規模の大きい 2 グループの点集合が観察できる.このように，スケ 一ルを変えて見てみると, 道路ネットワークに沿っ た集塊には，局所的なレベルからより大局的なレベ ルまでの多層性が存在しうることがわかる.

点の集塊に関しては, クランプ(Roach, 1968)とい う代表的な概念がある.クランプとは，平面上の点 の集合であり，その集合に属する全ての点は，それ らの点から所与の直線距離(これをクランプ半径と 呼ぶ) 以内の場所に，その点集合に属する点が少な くとも一つあるという性質をもつ点集合である.こ
のように定義された従来のクランプに対して，ここ では，従来の平面上のクランプの概念をネットワー ク上に拡張したクランプを用いることにする.すな わち, ネットワーク上のクランプとは, 前の定義の 「平面上」を「ネットワーク上」に，「直線距離」を 「最短経路距離」に置き換えたものである.

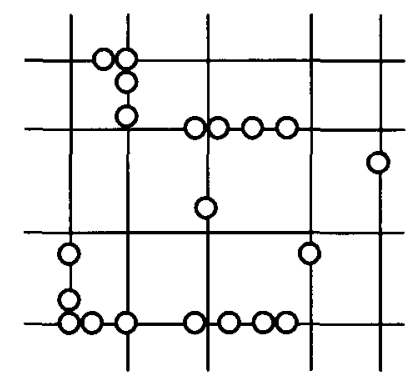

(a) ネットワーク上の 20 点

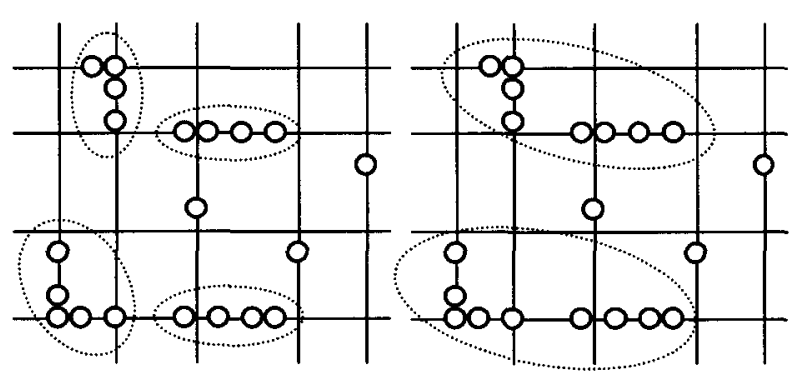

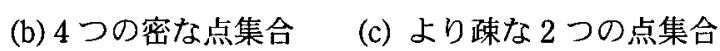

図 1 ネットワーク上の多層的な集塊

いま，ネットワーク距離で計測したクランプ半径 をパラメータとし，この值を徐々に拡大していくと， クランプ半径の変化に伴って，一つのクランプを構 成する点の数(これをクランプサイズと呼ぶ)や，こ れらのクランプの個数(これをクランプ数と呼ぶ)が 変化する.

本稿では，このクランプサイズごとのクランプ数 をクランプ半径の関数として, クランプ半径を小さ い值から大きい值へと変化させ，局所的なものから 大局的なものにわたる，多層的な点の集塊性を抽出 する方法を提案し，これをネットワーク可変クラン プ法と呼ぶことにする. また, ネットワーク可変ク ランプ法では，集塊性の抽出において，観察された 集塊性を均一ランダムな分布のもとで生成される集 塊性と比較することにより，統計的に有意な集塊性 を抽出することにする. 


\section{2 クランプの記述}

まず，ネットワーク空間上に $n$ 個の点 $p_{1}, p_{2}, \ldots, p_{n}$ が与えられたとき, クランプ半径 $r$ におけるクラン プサイズ $k$ のクランプ数を, $N(k \mid r)$ で表すことに する。そして，全体のクランプの状態を， $C(r)=(N(1 \mid r), N(2 \mid r), \ldots, N(n \mid r))$ とし，これを， クランプ状態と呼ぶことにする.

また，ノード $p_{i}$ から $p_{j}$ までのネットワーク上の 最短経路距離を， $d\left(p_{i}, p_{j}\right)$ で表すことにする．クラ ンプ半径を $d\left(p_{i}, p_{j}\right)$ で表しながら，図 2 (a)に示し たネットワーク上の13点の点集合を例にとって，ク ランプ状態がどのように変化するかを見てみよう。

$r=0$ から出発して, クランプ半径を徐々に拡大 していくと, $r=d\left(p_{3}, p_{4}\right)$ の時点で, 3 点の近傍点 で構成されるクランプが 2 組形成される(図 $2(\mathrm{~b})$ ). 図を見ると，互いに $d\left(p_{3}, p_{4}\right)$ 以内で立地している点 同士が，1つのクランプを形成していることがわか る(図中の太線で連結されている点が，同一クラン プに属する)。また，この時のクランプ状態を記述 すると,

$$
\begin{aligned}
& C\left(d\left(p_{3}, p_{4}\right)\right)= \\
& \left(N\left(k=1 \mid r=d\left(p_{3}, p_{4}\right)\right)=7,\right. \\
& N\left(k=2 \mid r=d\left(p_{3}, p_{4}\right)\right)=0, \\
& N\left(k=3 \mid r=d\left(p_{3}, p_{4}\right)\right)=2, \\
& \left.N\left(k=i \mid r=d\left(p_{3}, p_{4}\right)\right)=0,(i=4,5, \ldots, 13)\right),
\end{aligned}
$$
となる.

続いて，クランプ半径を徐々に拡大すると， $r=d\left(p_{9}, p_{10}\right)$ に至つた時点で， 4 点の近傍点で構成 されるクランプが 2 組形成される (図 $2(c))$. クラン プ半径をさらに拡大していくと, 図 2(d), 図 2(e) の状態を経て, $r=d\left(p_{2}, p_{5}\right)$ に達した時点(図 $2(\mathrm{f})$ ) で，全ての点が一つのクランプに集まる.このとき のクランプ半径 (図 2 の例では $d\left(p_{2}, p_{5}\right)$ )を $r_{\max }$ とす ると, ネットワーク上に $n$ 個の対象点が与えられた とき, 全点が一つのクランプに属した時のクランプ 状態は,

$$
\begin{aligned}
& C\left(r_{\max }\right)= \\
& \left(N\left(k=i \mid r=r_{\max }\right)=0,(i=1,2, \ldots, n-1),\right. \\
& \left.N\left(k=n \mid r=r_{\max }\right)=1\right),
\end{aligned}
$$

と表される.したがって，クランプの形成過程は,
$0 \leqq r \leqq r_{\max }$ の範囲におけるクランプ半径の多段階的 変化に対応して記述されることになる。

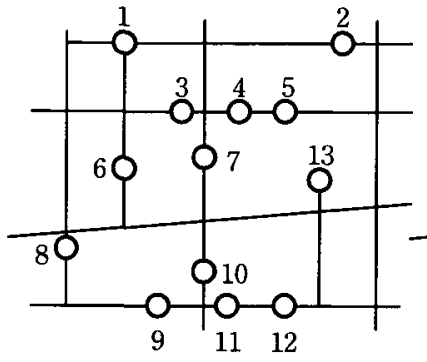

(a)

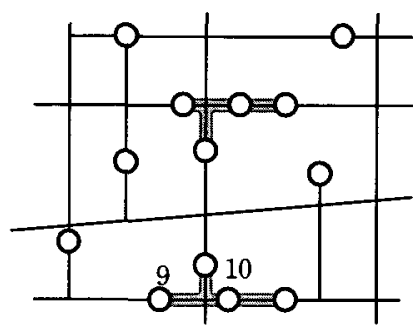

(c)

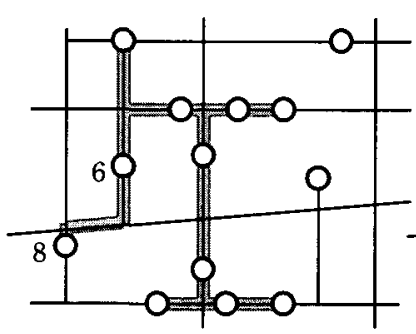

(e)

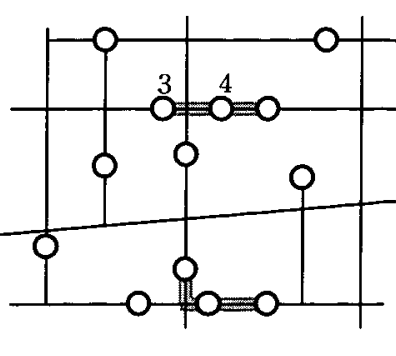

(b)

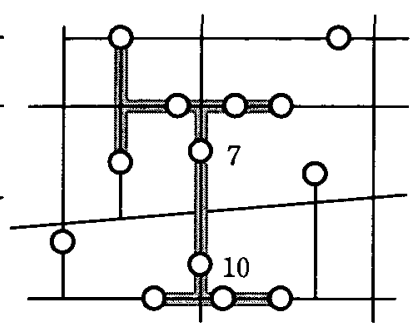

(d)

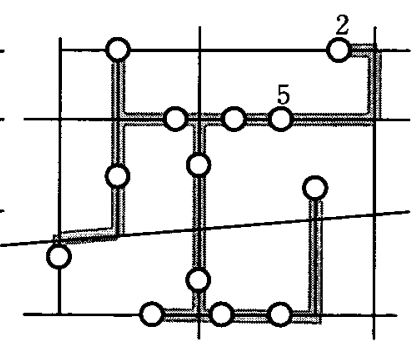

(f)

図 2 クランプ半径の拡大に伴って変化するクランプ

\section{3 多層的クランプの統計的検出}

対象点分布の中で，どのあたりの点集合が特異な ものであるか, すなわち，観測されたクランブ状態 の中で, どのクランプが特異なものであるかの特定 は，点がネットワーク上に均一ランダムに分布して いるときのクランプ状態と比較することによって実 現できる，そこで，観測点が分布しているネットワ 一クと同じネットワーク上にランダム点を発生させ, モンテカルロ・シミュレーションによって，特異な クランプを検出することにする.

前節で示したように，クランプ状態は，クランプ 半径が拡大する段階で, 点が新しくクランプに取り 
込まれたときに変化する，従って，観測分布のクラ ンプ状態が変化する時のクランプ半径と, 発生させ たランダム点分布のそれとは，多くの場合一致しな い. そこで，特異なクランプの検出を行う段階で両 者のクランプ状態を比較するためには，検出を行う 区間距離 $d_{0}$ を設定し，等間隔の検出区間距離 $d_{j}\left(d_{j}=j d_{0}, j=1,2, \ldots, m\right)$ (ただし $m$ は任意に設定 した検出カテゴリ数)ごこに, あらかじめ両者のク ランプ状態を記述しておかなければならない，観測 点分布の中から特異なクランプを検出する手順は, 次のようになる.

Step1 観 測 分布 のクランプ状態を $C^{0}(r)=\left(N^{0}(1 \mid r), N^{0}(2 \mid r), \ldots, N^{0}(n \mid r)\right)$ と し, $r=d_{j}\left(\right.$ ただし $\left.d_{1} \leqq d_{j} \leqq d_{m}, j=1,2, \ldots, m\right) の$ もとでの $C^{0}(r)$ を導出する.

Step2 分析対象領域のネットワーク上に, 観測分 布と同数のランダム点を発生させる.

Step3 ランダム点のクランプ状態を $C^{\mathrm{R}}(r)=\left(N^{\mathrm{R}}(1 \mid r), N^{\mathrm{R}}(2 \mid r), \ldots, N^{\mathrm{R}}(n \mid r)\right)$ 之 し, $r=d_{j}\left(d_{1} \leqq d_{j} \leqq d_{m}, j=1,2, \ldots, m\right)$ のもとで のランダム点の $C^{\mathrm{R}}(r)$ を導出する.

Step4 Step2,Step3を指定回数繰り返す.

Step5 Step4で得られた $C^{\mathrm{R}}(r)$ の各要素の $5 \%$ 上限 值を, クランプ検出の棄却域 $C^{\mathrm{R}}{ }_{\alpha}(r)=$ $\left(N_{\alpha}^{\mathrm{R}}(1 \mid r), N_{\alpha}^{\mathrm{R}}(2 \mid r), \ldots, N_{\alpha}^{\mathrm{R}}(n \mid r)\right)(\alpha=0.05)$ とし,$r=d_{j}\left(d_{1} \leqq d_{j} \leqq d_{m}, j=1,2, \ldots, m\right)$ の とでの $C^{\mathrm{R}}(r)$ を導出する ${ }^{1)}$.

Step6 $C^{0}(r)$ と $C^{\mathrm{R}}{ }_{\alpha}(r)$ の各要素を比較し， $N^{\mathrm{o}}\left(k=i \mid r=d_{j}\right)>N_{\alpha}^{\mathrm{R}}\left(k=i \mid r=d_{j}\right), \quad i=$ $2,3, \ldots, n, \quad j=1,2, \ldots m$ が成立するクランプ を, 統計的に有意なクランプとして(これ を以下では，統計的特異クランプと呼ぶ） 検出する.

クランプ半径が小さい段階で検出された統計的特 異クランプは，比較的狭い範囲のネットワーク上に 密集して立地する点集合である，それに対し，クラ ンプ半径が比較的大きくなつた段階で検出された場 合は，より広範囲に立地するやや緩やかな辌がりの
点集合であるといえよう.

\section{3. ネットワーク可変クランプ法の実装}

ネットワーク可変クランプ法の実装段階において は，ネットワーク上の最小木 (Network Minimum Spanning Tree, 以下これを NTMST と呼ぶ)を用い て，クランプ状態を記述すると効率がよい. NTMST とは，ネットワーク上の $n$ 個の点 $p_{1}, p_{2}, \ldots, p_{n}$ を頂 点とする連結なツリーのうちで，ツリーを構成する $(n-1)$ 本の枝（以下これを NTMSTリンクと呼ぶ） が，2 点間の最短経路であらわされ，且つNTMST リンクの総長が最小となるものである.

あるクランプ半径におけるクランプ状態は, 全 NTMST リンクから，そのクランプ半径より長いリ ンクを削除したときに，残ったリンクで接続された 点集合として得られる．そのため，クランブ状態を 導出するアルゴリズムでは，まず，NTMST を構築 しておき，その後，検出区間毎にクランプ状態を記 録していけばよい.

NTMST を導出するアルゴリズムとしては，以下 に示すネットワーク空間上でのボロノイ図と，その 双対グラフであるドローネ図を用いると効率的とな る.

いま，ネットワーク上に $n$ 点の点集合 $P=\left\{p_{1}, p_{2}, \ldots, p_{n}\right\}$ が与えられているとする.ネット ワーク上の任意の点 $p$ から点 $p_{i}$ までのネットワー ク上の最短経路距離を $d\left(p, p_{i}\right)$ とすると, $p_{i}$ のネッ トワーク上のボロノイ領域 $V\left(p_{i}\right)$ は,

$$
V\left(p_{i}\right)=\left\{p \mid d\left(p, p_{i}\right) \leq d\left(p, p_{j}\right), j \neq i, i, j=1, \ldots, n\right\}
$$

で与えられ，これをネットワークボロノイ図と呼ぶ もし $, i, j=1, \ldots, n(i \neq j)$ において, $V\left(\phi_{i}\right)$ と $V\left(\phi_{j}\right)$ が少 なくとも 1 点で境界を共有するなら， $p_{i}$ と $p_{j}$ をネッ トワーク上の最短経路で結ぶことにする．全ての $i, j=1, \ldots, n(i \neq j)$ について, 上の操作を行って出来 る図形を、ネットワークドローネ図と呼ぶ、つまり， ネットワーク空間上のドローネ図とは，隣接したボ ロノイ領域の母点同士をネットワーク上の最短経路 で連結した幾何グラフであるといえる.

こうして得られるネットワークドローネ図の部分 
グラフである NTMST は, 枝数 $O(n)$ であるネット ワークドローネ図を与えられたグラフ構造として, 最小木構築アルゴリズム（例えば， Prim, 1957; Kruskal, 1956)を用いて導くことができる.

以上の手順をまこめると, クランプ状態を導出す るまでの手続きは，以下のようになる(これは観測 分布においては, 2. 3 節のStep1, ランダム分布に 関しては, Step3の詳細にあたる).

Step1 ネットワークボロノイ図の生成

Step2 ネットワークドローネ図の生成

Step3 NTMST の生成

Step4 NTMST リンクのソート

Step5 検出区間距離 $r=d_{j}\left(d_{1} \leqq d_{j} \leqq d_{m}, j=1,2, \ldots\right.$ ， $m)$ におけるクランプ状態の記述

図 3 (a)に示した簡単なネットワーク上の点分布 から構築される，ネットワークボロノイ図，ネット ワークドローネ図, NTMSTを, 図 3(b) から図 3(d) に示した.

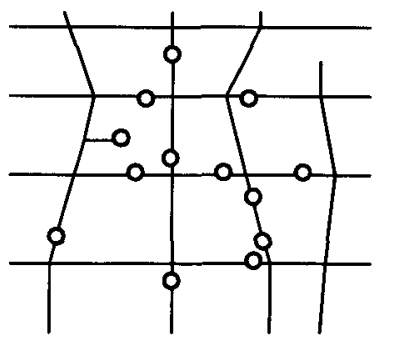

(a) ネットワーク上の 13 点

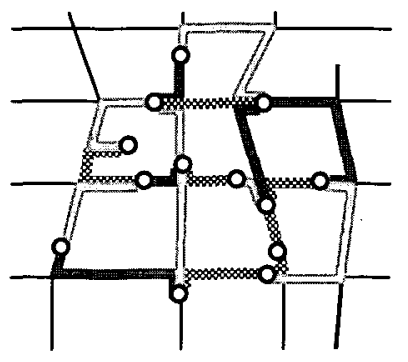

(c) ネットワークドローネ図

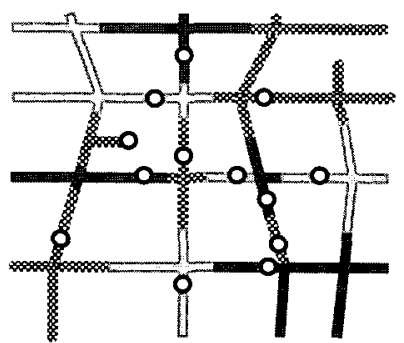

(b) ネットワークボロノイ図

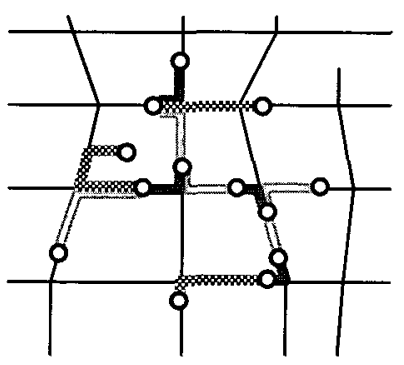

(d) NTMST
図 3 ネットワーク上の幾何図形
検出される統計的特異クランプは，区間距離の値 によって変化する，適切な区間距離というのは，点 分布の特徴をうまく要約する, すなわち，点分布の 特徵である集積をわかりやすく抽出するような距離 である，そこで，場合によっては，望ましい結果が 得られるまでこの距離を変化させて, クランブ検出 を繰り返す必要が生じる2．

\section{4. 実データを用いたネットワーク，平面可変 クランプ法の比較分析}

図 4 に示した領域 (東京都啮谷区内の $450 \mathrm{~m} \times$ $550 \mathrm{~m})$ と, 道路ネットワーク (総延長 $8428 \mathrm{~m})$, 及び ネットワーク上の点データ (290点の飲食店) を対象 に，前述のアルゴリズムに従って作成したプログラ ム (詳細は塩出 (2003) 参照. また本稿で提案した分 析手法は，ネットワーク上で空間分析を行う包括的 ツールSANET Ver.3 (Okabe et al., 2005) の一部とし て実装されている) を用いて，ネットワーク可変ク ランプ法を適用した.

検出区間距離を $5 \mathrm{~m}$ に設定してクランプ検出を行 つた結果, クランプ半径が $5 \mathrm{~m}$, 及び $10 \mathrm{~m}$ の段階で はクランプが検出されなかったため, 統計的特異ク ランプが検出された最小のクランプ半径は, $15 \mathrm{~m}$ と なった(図 5(a))。続いて, 図 5(b) から図5(e)の多 層的な統計的特異クランプを得た。

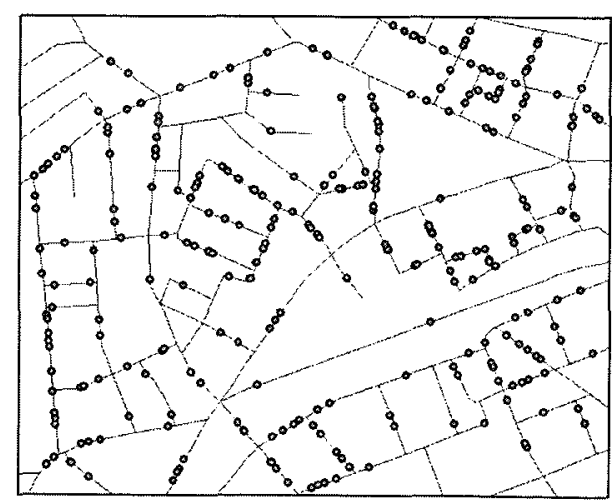

図 4 ネットワーク上の 290 点の飲食店 


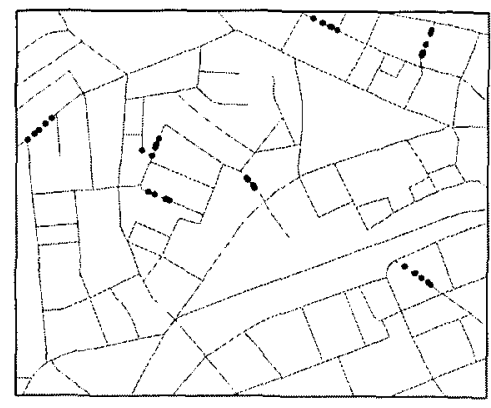

(a) クランプ半径 $15 \mathrm{~m}$

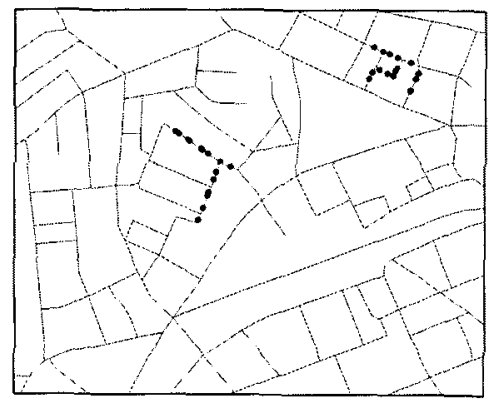

(b) クランプ半径 $20 \mathrm{~m}$

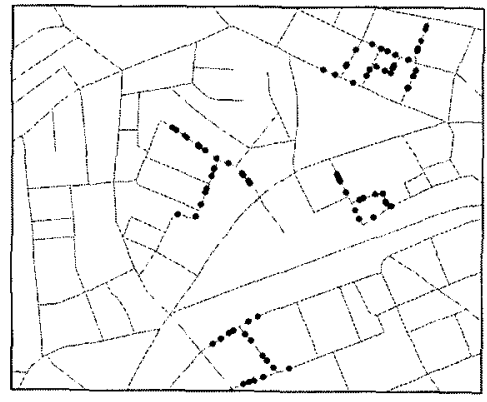

(c) クランプ半径 $25 \mathrm{~m}$

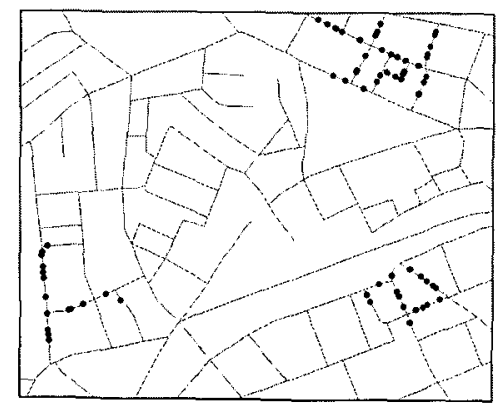

(d) クランプ半径 $30 \mathrm{~m}$

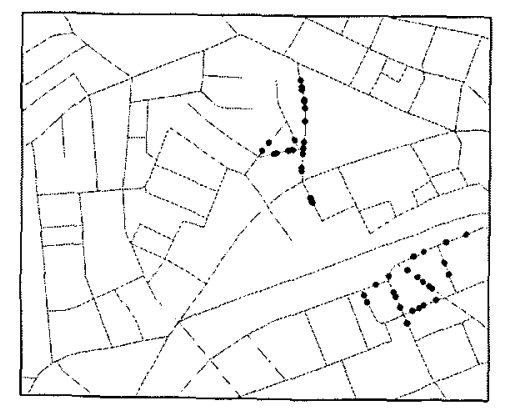

(e) クランプ半径 $35 \mathrm{~m}$

図 5 統計的特異ネットワーク・クランプ

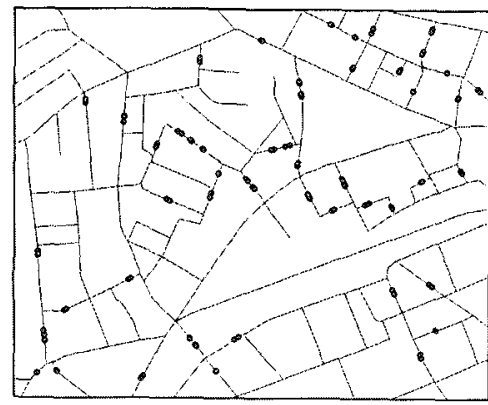

(a) クランプ半径 $12 \mathrm{~m}$

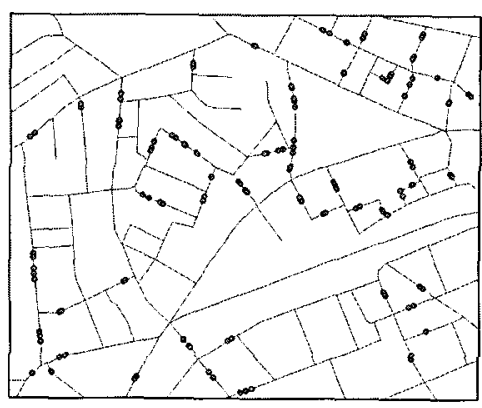

(b) クランプ半径 $16 \mathrm{~m}$

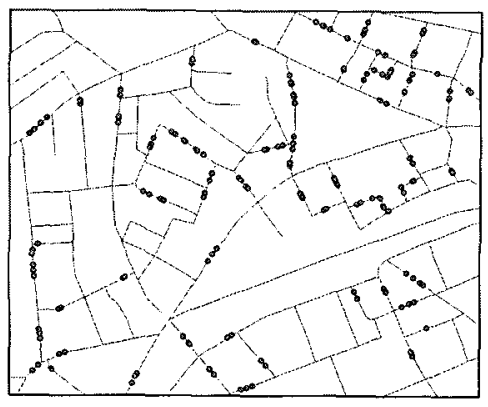

(c) クランプ半径 $20 \mathrm{~m}$

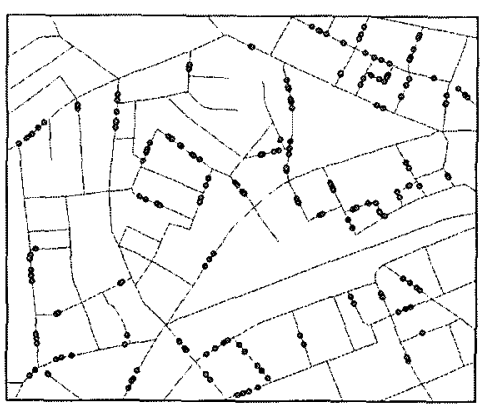

(d) クランプ半径 $24 \mathrm{~m}$

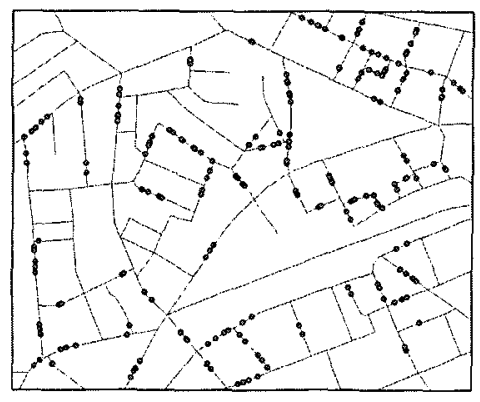

(e) クランブ半径 $28 \mathrm{~m}$

図 6 統計的特異平面クランプ 
この結果を平面上でのクランプ検出の結果と比較 するため, 同じデータに対して，平面上の可変クラ ンプ法(船本・岡部, 1998; Okabe and Funamoto, 2000）を適用した. ネットワーク上での分析と同レ ベルの検出区間距離で結果を導出するため, ネット ワーク上のクランプ検出に用いた $5 \mathrm{~m}$ に対して, 平 面上では， $4 \mathrm{~m}$ のクランプ半径を設定した(区間距 離の設定に関しては，2 点間のネットワーク距離は 直線距離の約1.29倍になるという, 腰塚 (1983)の実 証分析を参考にした).

$4 \mathrm{~m}$ の区間距離でクランプ検出を行ったところ, 図 6(a) から図 6(e) までの統計的特異クランプを得 た（例えば，図 5(a) と図 6(a)が，同レベルの距離 帯のペアである).

図 5 と図 6 を比較すると, ネットワーク上と平面 上それぞれで検出された統計的特異クランプに顕著 な違いがあることがわかる. 平面上のクランプの特 徵として, ぞのクランプ半径においても，比較的サ イズの小さいクランプが領域全体に数多く散らばつ ているということが挙げられる。例えば，図6(a)， 図 6(c), 図 6(e) の 3 段階のクランプ半径のもとで のそれぞれのクランプサイズの平均值は, 順に 2.22 , 2.54, 3.21であり, 大きな差がない. それに対して, ネットワーク上のクランプでは, 図 5(a), 図 5(c), 図 5(e)において，それぞれのクランプサイズの平 均値は，順に5.0，20.25，23.0と拡大している。こ れは，平面上のクランプとは対照的に，E゙のクラン プ半径においても, 数少ない特定の場所が集積地と して検出されていることによる，実際に図を見てみ ると，クランプサイズが拡大しながら，一本の道路 上に線的に形成されたもの (図 5(a)) から, 面的に つながったもの (図 5(b) 以降)へと,ネットワーク に沿ってクランプが変化している様子が見てとれる.

このような違いが現れた理由として，平面上とネ ットワーク上では, 近接点の特定と近隣点間の計測 距離に差があることが挙げられる。図 4 の点分布か ら導いたNTMST(図 7(a)) と, 平面上の最小木 (図 7 (b).これを以下 PLMST と呼ぶ)を比較してみよ う. PLMST リンクの中で, リンクの 2 端点の組み 合わせが NTMST リンクのそれと一致しないもの は，図7(c)に示す31本であった，図を見ると，こ れらのPLMSTリンクには，近接点までのネットワ 一ク距離とユークリッド距離が大きく乘離している ものが含まれており，PLMSTの場合，ネットワー ク上の実測距離ベースでは遠く離れた 2 点が近隣点 とされていることがわかる.

また, NTMSTリンクとPLMSTリンクの長さの頻 度分布を図 8 に示した。

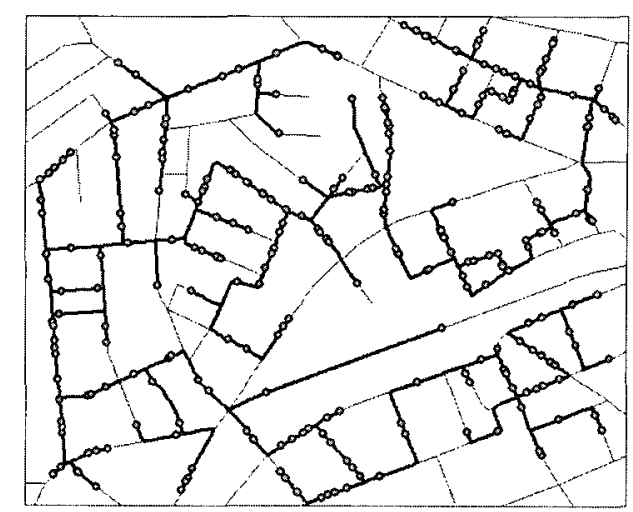

(a) ネットワーク最小木 (NTMST)

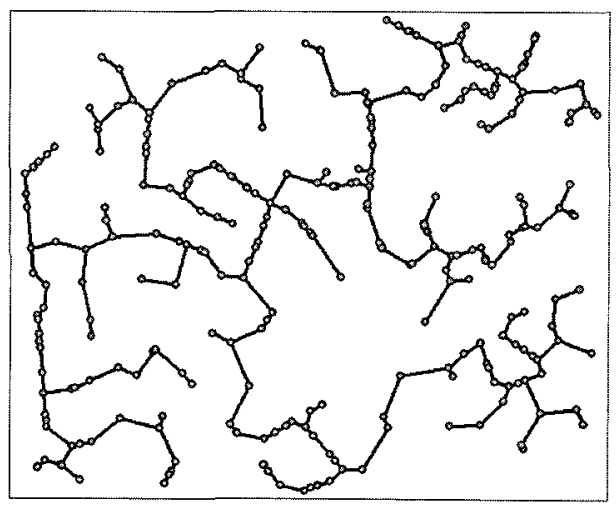

(b) 平面最小木 (PLMST)

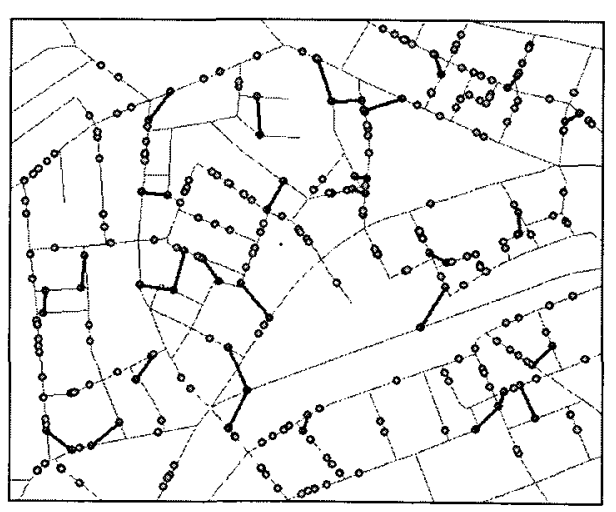

(c) (a)と(b)で隣接関係が一致しないリンク 図 7 最小木の比較 
これによると, リンクの長さが $35 \mathrm{~m}$ 超えると, PLMSTリンクの数が急速に減少する. 加えて, NTMSTリンク長の平均值が $18.93 \mathrm{~m}$ であるのに対し て，PLMSTリンク長の平均値は $15.07 \mathrm{~m}$ である。こ のことからも, 平面空間上では, 近接点間の距離が 過小評価されているということがわかる. それに対 して, ネットワーク上の可変クランプ法は, ネット ワーク上での点の連坦をより正確に捉えているとい えよう.

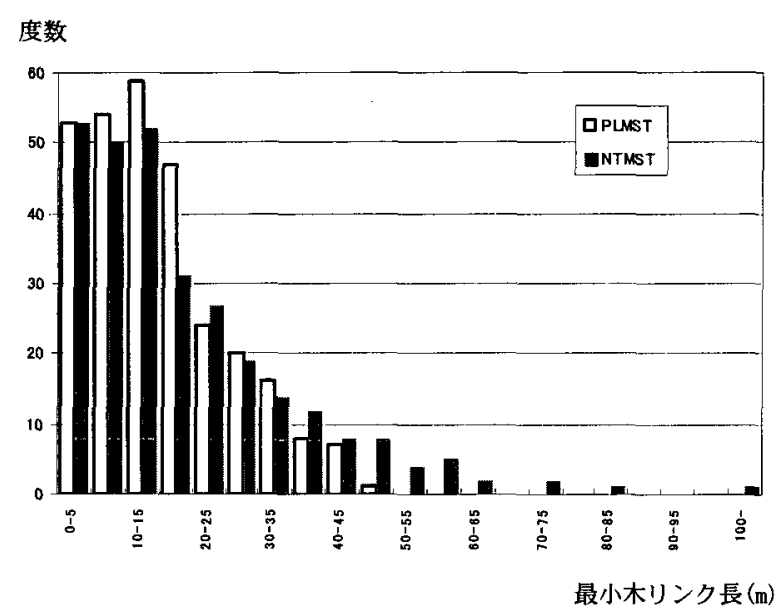

图 8 NTMSTリンクとPLMSTリンクの頻度分布

\section{5. 結論}

本稿では, ネットワーク上の点分布が与えられた とき, 各点から計測するネットワーク上の最短経路 距離を多段階的に変化させたときに形成される，ク ランプのサイズ, 及びクランプの個数の変化をもと に, 点分布の多層的な集塊性を検出する手法である, ネットワーク可変クランプ法を提案した.

実データを用いて，ネットワーク，平面，両空間 においてネットワーク可変クランプ法を適用した結 果, 位置, サイズ共に, 際立った違いのあるクラン プを検出した.さらに，その原因として，平面空間 上では各点間の距離を過小評価し，実際には近隣し ていない点同士を近接点として同じクランプに含め てしまうことによって，ネットワーク上の正確な隣 接関倸が記述できていないということを明らかにし た.

以上の結果から，1 章で挙げたような, ネットワ 一ク上で発生する, またはネットワークに強く規定
される事象を分析対象とする場合には，ネットワー ク可変クランプ法を適用することによって, より厳 密な結果を導くことができる, すなわち，集積場所 の的確な抽出が可能になるといえよう。例えば，本 稿で例として用いた商業施設などは, 街路沿いの集 塊性が意味を持つことから、ネットワーク距離で分 析することが適切な一例であろう。

ネットワーク空間で分析することの有効性は, 例 えば，河川や鉄道など，空間を分断する障害物を隔 てて施設の集積が広がっている場合などに，より顕 著となる．平面上でのクランプ検出では，これらの 障害物の両側に立地する施設間の距離を直線距離で 計測してしまうため，抽出された集積は，実際には 分断されており，一群の集積とはいえないことがあ る. それに対して，ネットワーク空間上での分析で は，障害物を横断するために存在する道路や橋等の 通路に関する情報を分析に取り入れ，実際の経路距 離で点の近接性を判断するため，現実の移動空間上 の点の連続性を分析結果に反映することが可能とな る.

また，このように現象をより的確に把握すること は，ネットワーク上で発生する様々な現象のメカニ ズムを解明する分析を行う上で，大いに役立つと考 えられる.ネットワーク可変クランプ法の利点とし て，検出された集塊の位置とサイズ，及び集塊の密 集度を導出できるということが挙げられる．このこ とによって，本論文の適用分析で示したような，都 市空間の様々な施設を分析対象とする場合には，集 積の密集度を考慮した分析が可能になり，また事故 や犯罪への対策を検討する分析を行う場合には，現 象の発生密度に合わせて対策の優先順位を検討する といった, より綿密な分析が可能になるといえよう.

\section{謝辞}

本研究は, 科学研究費補助金 (日本学術振興会特 別研究員奨励費)，及び，科研費特定 (B) 領域番号 602 「人文社会科学の空間情報科学」(領域代表： 岡部篤行教授)による研究成果の一部である.

本稿をまとめるにあたり，多くの方々のご助言， ご意見をいただいた．浅見泰司教授（東京大学空間 
情報科学研究センター), 貞広幸雄助教授 (東京大 学工学部都市工学科), 小出治教授 (東京大学工学 部都市工学科), 清水英範教授 (東京大学工学部土 木工学科), 塩出徳成助教授 (ニューヨーク州立大 学バッファロー校地理学科) にこの場で感謝の意を 表したい.

\section{注}

1) 各クランプ半径におけるクランプ数は，互いに確率 的に独立ではない．シミュレーションによる方法で はその点が考虑されないが，実用上は問題ない。

2) 区間距離の設定の際は， $r_{\text {max }}$ (厳密な $r_{\text {max }}$ 值が特定で きない場合は，それに近いと思われる値)を適度な数 (例えば20から30の間の值)で割った值を区間距離の 目安にするとよい，また，設定した区間距離でクラ ンブ検出を行った結果, 隣り合う複数のクランプ半 径において同一のクランプが多く検出された場合, 区間距離をそれより少し大きくして調整するとよい.

\section{参考文献}

腰塚武志, 小林純一（1983）道路距離之直楾距離, 「昭和 58 年度日本都市計画学会学術研究発表会論文集」, 43-48.

塩出志乃（2003）ネットワーク上の空間分析手法とその 実装化に関する研究, 東京大学工学部都市工学科博 士論文.

船本志乃，岡部篤行（1998）点分布の空間階層的特性を 抽出する探索的解析ツールの開発，「GIS-理論と応 用」, 6 (1)，49-58.

四茂野英彦（1993）ネットワーク上での最近接距離分布 の計算可能性,「GIS-理論と応用」, 1, 47-56.

Clark, P. J. and F. C. Evans (1954) Distance to Nearest Neighbor as a Measure of Spatial Relationships in Populations. Ecology, 35, 445-453.
Kruskal, J. B. (1956) On the Shortest Spanning Subtree of a Graph and the Traveling Salesman Problem., Proceedings of the American Mathematical Society, 7, 48-50.

Miller, H. J. (1994) Market Area Delimitation within Networks using Geographic Information Systems, Geographical Systems, 1 (2),157-173.

Miller, H. J. (1999) Measuring Space-time Accessibility Benefits within Transportation Networks: Basic Theory and Computational Methods, Geographical Analysis, 31, 187-212.

Okabe, A. and Funamoto, S. (2000) An Exploratory Method for Detecting Multi-Level Clumps in the Distribution of Points, Geographical Systems, 2 (2), 111-120.

Okabe, A. and Okunuki, K. (2001) A Computational Method for Estimation the Demand of Retail Stores on a Street Network and its Implementation in GIS, Transactions in GIS, 5 (3), 209-220.

Okabe, A., Yomono, H. and Kitamura, M. (1995) Statistical Analysis of the Distribution of Points on a Network, Geographical Analysis, 27 (2), 152-175.

Okabe, A., Okunuki, K. and Shiode, S. (2005) SANET : A Toolbox for Spatial Analysis on a Network Verision 3.0, Center for Spatial Information Science, University of Tokyo.

http://okabe.t.u-tokyo.ac.jp/okabelab/atsu/sanet/sanetindex.html

Okabe, A. and Yamada, I. (2001) The K-function method on a network and its computational implementation, Geographical Analysis, 33 (3) , 271-290.

Prim, R. C. (1957) Shortest Connection Networks and Some Generalizations, Bell System Technical Journal, 36, 13891401.

Ripley, B. D. (1981) Spatial Statistics, New York: Wiley.

Roach, S. A. (1968) The Theory of Random Clumping, Methuen. 